\title{
Childhood Subependymal Giant Cell Astrocytoma
}

National Cancer Institute

\section{Source}

National Cancer Institute. Childhood Subependymal Giant Cell Astrocytoma. NCI

Thesaurus. Code C114785.

Subependymal giant cell astrocytoma that occurs during childhood. 